Article

\title{
A Test of the Inadvertent Uptake Hypothesis Using Plant Species Adapted to Serpentine Soil
}

\author{
George A. Meindl ${ }^{1, *,+}$, Mark I. Poggioli ${ }^{1,+}$, , Daniel J. Bain ${ }^{2}$, Michael A. Colón ${ }^{1}$ and Tia-Lynn Ashman ${ }^{3}$ \\ 1 Environmental Studies Program, Binghamton University, Binghamton, NY 13903, USA; \\ mpoggio1@binghamton.edu (M.I.P.); mcolon3@binghamton.edu (M.A.C.) \\ 2 Department of Geological Sciences, University of Pittsburgh, Pittsburgh, PA 15260, USA; dbain@pitt.edu \\ 3 Department of Biological Sciences, University of Pittsburgh, Pittsburgh, PA 15260, USA; tia1@pitt.edu \\ * Correspondence: gmeindl@binghamton.edu \\ + Authors made equal contribution.
}

Citation: Meindl, G.A.; Poggioli,

M.I.; Bain, D.J.; Colón, M.A.; Ashman, T.-L. A Test of the Inadvertent Uptake Hypothesis Using Plant Species Adapted to Serpentine Soil. Soil Syst. 2021, 5, 34. https://doi.org/10.3390/ soilsystems 5020034

Academic Editor: Adriano Sofo

Received: 20 May 2021

Accepted: 16 June 2021

Published: 18 June 2021

Publisher's Note: MDPI stays neutral with regard to jurisdictional claims in published maps and institutional affiliations.

Copyright: (c) 2021 by the authors. Licensee MDPI, Basel, Switzerland. This article is an open access article distributed under the terms and conditions of the Creative Commons Attribution (CC BY) license (https:// creativecommons.org/licenses/by/ $4.0 /)$.

\begin{abstract}
Serpentine soils are a stressful growing environment for plants, largely due to nutrient deficiencies and high concentrations of toxic heavy metals (e.g., Ni). Plants have evolved various adaptations for tolerating these extreme environments, including metal hyperaccumulation into above-ground tissues. However, the adaptive significance of metal hyperaccumulation is a topic of debate, with several non-mutually-exclusive hypotheses under study. For example, the inadvertent uptake hypothesis (IUH) states that heavy metal accumulation is a consequence of an efficient nutrient-scavenging mechanism for plants growing in nutrient-deficient soils. Thus, it is possible that metal hyperaccumulation is simply a byproduct of non-specific ion transport mechanisms allowing plants to grow in nutrient-deficient soils, such as serpentine soils, while simultaneously tolerating other potentially toxic heavy metals. Furthermore, some nutrient needs are tissue-specific, and heavy metal toxicity can be more pronounced in reproductive tissues; thus, studies are needed that document nutrient and metal uptake into vegetative and reproductive plant tissues across species of plants that vary in the degree to which they accumulate soil metals. To test these ideas, we grew nine plant species that are variously adapted to serpentine soils (i.e., Ni-hyperaccumulating endemic, nonhyperaccumulating endemic, indicator, or indifferent) in a common garden greenhouse experiment. All species were grown in control soils, as well as those that were amended with the heavy metal $\mathrm{Ni}$, and then analyzed for macronutrient $(\mathrm{Ca}, \mathrm{Mg}, \mathrm{K}$, and $\mathrm{P})$, micronutrient $(\mathrm{Cu}, \mathrm{Fe}, \mathrm{Zn}, \mathrm{Mn}$, and $\mathrm{Mo})$, and heavy metal ( $\mathrm{Cr}$ and $\mathrm{Co}$ ) concentrations in their vegetative and reproductive organs (leaves, anthers, and pistils). In accordance with the IUH, we found that hyperaccumulators often accumulated higher concentrations of nutrients and metals compared to non-hyperaccumulating species, although these differences were often organ-specific. Specifically, while hyperaccumulators accumulated significantly more $\mathrm{K}$ and $\mathrm{Co}$ across all organs, $\mathrm{Cu}$ was higher in leaves only, while Mn and Zn were higher in anthers only. Furthermore, hyperaccumulators accumulated significantly more Co and Mo across all organs when Ni was added to the soil environment. Our work provides additional evidence in support of the IUH, and contributes to our understanding of serpentine adaptation in plants.
\end{abstract}

Keywords: hyperaccumulation; Brassicaceae; serpentine; heavy metals; nickel; edaphic; inadvertent uptake hypothesis

\section{Introduction}

Serpentine soils represent a unique growing environment for plants, largely due to their chemical composition. These soils are characterized by a low a Ca:Mg ratio, generally low water-holding capacity, and elevated concentrations of heavy metals such as $\mathrm{Co}, \mathrm{Cr}$, and $\mathrm{Ni}[1,2]$. Furthermore, these soils generally contain scarce levels of essential macronutrients such as N, P, and S [3]. These stressful edaphic conditions have given rise to a unique set of flora adapted to serpentine ecosystems. 
The abundance of toxic heavy metals, including $\mathrm{Co}, \mathrm{Cr}$, and $\mathrm{Ni}$, is often cited as a stressful aspect for plant growth in serpentine soils $[4,5]$. While most heavy-metal-tolerant plants are able to effectively exclude these metals from their above-ground tissues (e.g., serpentine-adapted plants [6]), preventing toxicity, a small group of plants known as metal hyperaccumulators absorb exceptionally high concentrations of these elements into their above-ground tissues $[7,8]$. There are roughly 750 plant species that can hyperaccumulate various heavy metals and metalloids, although the majority ( $>500)$ accumulate Ni [9]. The adaptive significance of hyperaccumulation remains largely unexplained (reviewed in [10]).

There are several non-mutually-exclusive hypotheses for the adaptive significance of metal hyperaccumulation. The "elemental defense hypothesis" has received the most support, and proposes that increased metal accumulation deters herbivores and/or pathogens, thus providing a chemical defense against enemies [11,12]. The "elemental allelopathy hypothesis" presumes that, through leaf shedding, hyperaccumulating plants can enrich the surrounding soil with toxic metals, thereby inhibiting neighboring plants from growing in close proximity [13]. The "drought resistance hypothesis" holds that metals serve to inhibit transpiration, which assists in osmotic adjustment for plants inhabiting shallow, porous, and rocky soils [14]. Lastly, the "inadvertent uptake hypothesis" (IUH) states that heavy metal accumulation is a consequence of an efficient nutrient-scavenging mechanism for plants growing in nutrient-deficient soils [13]. First proposed by Boyd and Martens [15], this hypothesis is not widely tested, but some studies provide it with limited support. For example, Boyd and Jaffré [16] found a positive correlation between Ni and Fe uptake in 11 woody species found in serpentine soils in New Caledonia. In addition, studies focusing on nutrient uptake for As hyperaccumulators show that non-hyperaccumulators grown on the same As-amended soil were less efficient in $\mathrm{Fe}, \mathrm{Zn}$, and $\mathrm{K}$ uptake compared to hyperaccumulators Pteris vittata and P. multifada [17]. Thus, it is possible that metal hyperaccumulation is simply a byproduct of non-specific ion transport mechanisms allowing plants to grow in nutrient-deficient soils, such as serpentines.

Patterns of plant nutrient accumulation often vary across tissue types, as certain nutrients may be needed in relatively higher concentrations in specific organs. For example, Ca concentrations are generally much higher in leaves compared to flowers, as $\mathrm{Ca}$ is an important structural component of cell walls and membranes (reviewed in [18]). Copper, on the other hand, is known to regulate flower and fruit formation, and $\mathrm{Cu}$ concentrations of fruits can be higher than those of roots for plants with adequate $\mathrm{Cu}$ supply [19]. Therefore, rigorous tests of the IUH need to evaluate macronutrient and micronutrient concentrations across the vegetative and reproductive plant organs of hyperaccumulator and non-hyperaccumulator plants growing in common environments. A handful of recent studies have documented macronutrient and micronutrient concentrations in the vegetative and reproductive tissues of hyperaccumulator plants in the field [20,21], but none have compared hyperaccumulators vs. non-hyperaccumulators in a controlled experimental context adequate for testing the IUH.

Interactions among metals have been reported for various hyperaccumulators and other serpentine taxa. Numerous studies provide evidence for simultaneous uptake, competition, and co-tolerance, and point toward a relatively non-specific metal uptake mechanism [22-25]. For example, Noccaea caerulescens is a hyperaccumulator of multiple heavy metals, and experiments show that the addition of $\mathrm{Ni}$ can influence the uptake of other trace elements (e.g., $\mathrm{Ni}$ treatment increased Fe uptake, but decreased $\mathrm{Cu}$ and $\mathrm{Mn}$ uptake [26]). Similarly, the addition of Ni to treatment soils lowered Co accumulation in two species of Ni hyperaccumulators (Alyssum murale and A. corsicum), and Ni accumulation was suppressed following the experimental addition of Co $[27,28]$. Nickel has also been shown to stimulate the uptake of $\mathrm{Mn}$ in these two species of Alyssum [29]. Collectively, these trends lend credence to the hypothesis of inadvertent Ni hyperaccumulation due to nonspecific metal transporters located in the roots as a result of metal co-tolerance. Evidence of co-tolerance and co-accumulation would also support the IUH, under the assumption that plants growing in metal-rich soils must have mechanisms to either accumulate or exclude 
all excess metals in order to access nutrient ions. However, a key comparison for testing the IUH is whether Ni concentrations in serpentine soils differentially influence nutrient uptake for hyperaccumulating and non-accumulating plant species, and this has yet to be performed.

In this study, we address this gap by determining the scavenging abilities for macronutrients $(\mathrm{Ca}, \mathrm{Mg}, \mathrm{K}$, and $\mathrm{P})$, micronutrients $(\mathrm{Cu}, \mathrm{Fe}, \mathrm{Zn}, \mathrm{Mn}$, and $\mathrm{Mo})$, and heavy metals $(\mathrm{Cr}$ and $\mathrm{Co}$ ) commonly associated with serpentine soils of nine plant species spanning four serpentine soil affinities (hyperaccumulating endemic, non-hyperaccumulating endemic, indicator, and indifferent $[30,31])$. Furthermore, we determined whether elemental uptake is affected by Ni concentrations in the soil environment, by type of organ, or by element. We hypothesize that Ni-hyperaccumulating plants will accumulate higher concentrations of non-Ni elements across their above-ground tissues, in accordance with the inadvertent uptake hypothesis.

\section{Materials and Methods}

\subsection{Study System}

Nine species in the family Brassicaceae (Table 1) were chosen based on serpentine soil affinity, ranging from indifferent $(\leq 45 \%$ occurrence in serpentine soils) to strictly endemic $(\geq 95 \%$ ). The Brassicaceae family is an excellent model for the study of metal hyperaccumulation, as it accounts for approximately $25 \%$ of all hyperaccumulating species [9,32]. We calculated affinity scores based on nomenclature used at the time of this study (Safford et al., 2005 [30], but see Safford and Miller [31] for an updated database), but for two species-S. tortuosus var. suffrutescens (now S. tortuosus) and Arabis breweri (now Boechera breweri) — we used an updated nomenclature [33]. All study species are springflowering herbaceous perennials or annuals, five of which are only found in California, while the remaining four are known to occur more broadly (Table 1). In the summer of 2012, seeds were bulk collected from single populations in serpentine soils representing each taxon.

Table 1. Study species and their serpentine affinity scores from Safford et al. [30,31]; hyperaccumulating species in bold. Plants were divided into three categories: serpentine endemic, serpentine indicator, or serpentine indifferent. Species not discussed by Safford et al. [30] are given an affinity score of " $<1$ ". Life history (annual or perennial) and distribution ranges are provided for all species (CA: California; NA: North America; AE: Afro-Eurasia). This table is modified from Meindl et al. [34].

\begin{tabular}{|c|c|c|c|c|c|}
\hline Species & Plant Category & Affinity Score & Life History & Range & $\begin{array}{l}\text { Seed Collection } \\
\text { Location }\end{array}$ \\
\hline $\begin{array}{l}\text { Streptanthus } \\
\text { polygaloides }\end{array}$ & Hyperaccumulating Endemic & 6 & Annual & CA & $\begin{array}{l}\text { N } 39^{\circ} 46^{\prime} 50.4^{\prime \prime} \\
\text { W } 121^{\circ} 28^{\prime} 41.6^{\prime \prime}\end{array}$ \\
\hline $\begin{array}{l}\text { Noccaea fendleri ssp. } \\
\text { glauca }\end{array}$ & Hyperaccumulating Endemic & 4.4 & Perennial & Western NA & $\begin{array}{c}\text { N } 41^{\circ} 16^{\prime} 42.4^{\prime \prime} \\
\text { W } 122^{\circ} 41^{\prime} 48.7^{\prime \prime}\end{array}$ \\
\hline S. breweri var. breweri & Non-hyperaccumulating Endemic & 5.7 & Annual & CA & $\begin{array}{c}\text { N } 38^{\circ} 51^{\prime} 52.4^{\prime \prime} \\
\text { W } 122^{\circ} 24^{\prime} 16.4^{\prime \prime}\end{array}$ \\
\hline S. morrisonii & Non-hyperaccumulating Endemic & 6.1 & Perennial & CA & $\begin{array}{c}\text { N } 38^{\circ} 48^{\prime} 45.3^{\prime \prime} \\
\text { W } 122^{\circ} 22^{\prime} 54.9^{\prime \prime}\end{array}$ \\
\hline $\begin{array}{l}\text { S. glandulosus ssp. } \\
\text { glandulosus }\end{array}$ & Indicator & 1.9 & Annual & CA & $\begin{array}{c}\text { N } 38^{\circ} 51^{\prime} 43.9^{\prime \prime} \\
\text { W } 122^{\circ} 23^{\prime} 57.3^{\prime \prime}\end{array}$ \\
\hline S. tortuosus & Indicator & 1.7 & Perennial & Western NA & $\begin{array}{l}\text { N } 39^{\circ} 59^{\prime} 18.4^{\prime \prime} \\
\text { W } 121^{\circ} 17^{\prime} 19.8^{\prime \prime}\end{array}$ \\
\hline $\begin{array}{c}\text { Erysimum capitatum } \\
\text { var. capitatum }\end{array}$ & Indifferent & $<1$ & Perennial & NA & $\begin{array}{c}\mathrm{N} 41^{\circ} 16^{\prime} 32.5^{\prime \prime} \\
\mathrm{W} 122^{\circ} 41^{\prime} 54.4^{\prime \prime}\end{array}$ \\
\hline Hirschfeldia incana & Indifferent & $<1$ & Annual & $\mathrm{NA}, \mathrm{AE}$ & $\begin{array}{c}\text { N } 38^{\circ} 51^{\prime} 30.0^{\prime \prime} \\
\text { W } 122^{\circ} 24^{\prime} 35.2^{\prime \prime}\end{array}$ \\
\hline Boechera breweri & Indifferent & $<1$ & Perennial & CA & $\begin{array}{l}\text { N } 39^{\circ} 57^{\prime} 12.3^{\prime \prime} \\
\text { W } 121^{\circ} 19^{\prime} 4.5^{\prime \prime}\end{array}$ \\
\hline
\end{tabular}




\subsection{Experimental Design}

Greenhouse experiments were conducted during the fall of 2012 at the University of Pittsburgh. Twenty plants per species $(\mathrm{N}=180)$ were grown in Ni-amended and control soils. Prior to planting, we exposed the seeds to $4{ }^{\circ} \mathrm{C}$ cold and dark conditions for 2 weeks. Then, 2 weeks following germination, seedlings were transplanted to $27 \mathrm{~cm}^{3}$ "rocket pots" (Deepots, Stuewe and Sons, Inc., Tangent, OR, USA) containing standard potting soil (Fafard \#4; Sun Gro Horticulture, Agawam, MA, USA) and amended with six Nutricote ${ }^{\circledR}$ NPK 13-13-13 time-release fertilizer pellets (Arysta Lifescience Corporation, NY, New York, USA). After 1 month of growth in the rocket pots, perennials were subjected to a $4{ }^{\circ} \mathrm{C}$ cold period for 1 month at 8D:16N. Following this treatment, perennials and annuals were grown in controlled conditions at 12D:12N, between 21 and $27^{\circ} \mathrm{C}$, until plants began flowering.

One month after planting annuals, or 1 week after cold treatment of perennials, 10 plants per species were treated with a (1) Ni nitrate $\left(\mathrm{Ni}\left(\mathrm{NO}_{3}\right)_{2}-6 \mathrm{H}_{2} \mathrm{O}\right)$ solution $(40 \mathrm{~mL}$ of $400 \mathrm{mg} \mathrm{kg}{ }^{-1}$ ) and ten were treated with (2) ammonium nitrate $\left(\mathrm{NH}_{4} \mathrm{NO}_{3}\right)$ solution. This latter treatment served as a control solution by adjusting for the additional $190 \mathrm{ppm}$ $\mathrm{N}$ in the Ni-amended soil. Our Ni treatment accurately represents bioavailable $\mathrm{Ni}$ in serpentine soils, as the bioavailable fractions of $\mathrm{Ni}$ range from 50 to $500 \mathrm{ppm} \mathrm{Ni}$ [35-37]. The treatments were applied to individual plants until they produced flowers for analysis, which varied from $4-18$ weeks. All plants were watered as necessary.

\subsection{Tissue Collection and Chemical Analysis}

Above-ground vegetative and reproductive organs (leaves, and pistils and anthers, respectively) were collected individually from plants for chemical analysis. A single mature leaf was removed following four soil treatment applications. Pistils and anthers were collected from the first 5-15 flowers to bloom. While leaves were collected from every plant $(\mathrm{N}=10$ per species/soil treatment), some plants $(\mathrm{N}=5)$ never flowered and, thus, 7-10 plants were sampled per species/soil treatment for floral organs. In preparation for chemical analysis, leaves and pistils were rinsed with $\mathrm{diH}_{2} \mathrm{O}$ and dried at $60{ }^{\circ} \mathrm{C}$ for $48 \mathrm{~h}$. Anthers were placed in microcentrifuge tubes and allowed to dry for $48 \mathrm{~h}$. All organ samples were weighed to the nearest $0.0001 \mathrm{~g}$ on a AE200 Mettler ${ }^{\circledR}$ analytical balance (Mettler-Toledo; LLC, Columbus, OH, USA) and microwave digested in 2-4 mL trace-metalgrade $\mathrm{HNO}_{3}$ before being diluted to a final volume of $12-14 \mathrm{~mL}$ with MilliQ (Millipore, Bedford, MA, USA) $\mathrm{H}_{2} \mathrm{O}$. We report Ni concentrations in $\mathrm{mg} / \mathrm{kg}$ (ppm) for all organs. Chemical concentrations in tissues were determined using inductively coupled plasma mass spectrometry (ICP-MS, NeXION 300X, PerkinElmer, Waltham, MA, USA) at the University of Pittsburgh.

\subsection{Statistical Analysis}

All statistical analyses were conducted using SAS software (2013; version 9.4; SAS Institute Inc., Cary, NC, USA). A mixed-model ANCOVA was used (PROC MIXED) to evaluate the effect of $\mathrm{Ni}$ soil treatment, serpentine habitat affinity, and organ type on elemental/nutrient uptake for each element separately. This model included soil treatment (Ni-supplemented, control), serpentine habitat affinity (endemic, indicator, indifferent, hyperaccumulator), organ type (leaves, pistils, anthers), and their interactions and random factors of plant and species, where species was nested within serpentine habitat affinity. The quantity of soil treatment applications (Ni amendment) was included as a covariate. Denominator degrees of freedom used in F-tests were determined using the Kenward-Roger approximation, which is recommended for small sample sizes and unbalanced data [38]. Pairwise comparisons across organ and habitat affinity types were made using TukeyKramer tests. For all analyses, Ni concentrations were log or natural-log transformed to improve the normality of the residuals. Back-transformed lsmeans (and 95\% confidence intervals) of $\mathrm{Ni}$ concentrations are presented in figures for clarity. Because our hypotheses specifically relate to comparisons of hyperaccumulators vs. other serpentine affinity categories, we focus our results on the main effects of soil affinity, organ type, and Ni treatment, 
and only model statistical interactions involving soil affinity (i.e., affinity $\times$ organ type, affinity $\times$ Ni treatment, affinity $\times$ organ type $\times$ Ni treatment). There were no significant major soil affinity effects or interactions in the models for the micronutrient $\mathrm{Fe}$; thus, results for this element are not presented in detail below (but see Table 2 for results from all models). For Ni concentrations in plant tissues in this experiment, see Meindl et al. [34,39].

Table 2. Results of mixed-model ANCOVA to evaluate the effect of serpentine habitat affinity, Ni treatment, and organ type on plant uptake of macronutrients, micronutrients, and heavy metals. Bold text indicates statistical significance.

\begin{tabular}{|c|c|c|c|c|c|c|c|c|c|c|c|}
\hline \multirow[b]{2}{*}{ Factor } & \multicolumn{4}{|c|}{ Macronutrients } & \multicolumn{5}{|c|}{ Micronutrients } & \multicolumn{2}{|c|}{ Heavy Metals } \\
\hline & $\mathrm{K}$ & $\mathrm{P}$ & $\mathrm{Ca}$ & $\mathrm{Mg}$ & $\mathrm{Zn}$ & $\mathrm{Cu}$ & Mo & $\mathrm{Fe}$ & $\mathrm{Mn}$ & Co & $\mathrm{Cr}$ \\
\hline Affinity (A) & 0.05 & 0.32 & 0.34 & 0.37 & 0.16 & 0.36 & 0.62 & 0.25 & 0.29 & $<0.001$ & 0.16 \\
\hline $\begin{array}{l}\text { Ni Treatment } \\
\text { (NT) }\end{array}$ & 0.5 & 0.12 & 0.95 & 0.86 & $<0.001$ & $<0.05$ & 0.55 & 0.59 & 0.5 & $<0.0001$ & 0.07 \\
\hline Organ Type (OT) & $<0.0001$ & $<0.0001$ & $<0.0001$ & $<0.0001$ & $<0.001$ & $<0.0001$ & $<0.0001$ & $<0.0001$ & 0.7 & $<0.01$ & $<0.001$ \\
\hline $\mathrm{A} \times \mathrm{OT}$ & $<0.0001$ & $<0.0001$ & $<0.0001$ & $<0.0001$ & $<0.0001$ & $<0.0001$ & $<0.0001$ & 0.18 & $<0.0001$ & $<0.0001$ & $<0.001$ \\
\hline $\mathrm{A} \times \mathrm{NT}$ & 0.56 & 0.7 & 0.92 & 0.68 & 0.48 & 0.63 & $<0.001$ & 0.4 & 0.7 & $<0.0001$ & 0.59 \\
\hline $\mathrm{A} \times \mathrm{OT} \times \mathrm{NT}$ & 0.71 & 0.77 & 0.98 & 0.66 & 0.5 & 0.61 & 0.24 & 0.39 & 0.79 & 0.74 & 0.31 \\
\hline
\end{tabular}

\section{Results}

\subsection{Macronutrients}

\subsubsection{Potassium}

There were significant differences in K concentrations across the soil affinity categories, with hyperaccumulating endemic plants taking up 34\% more $\mathrm{K}$ than non-hyperaccumulating endemic, 33\% more than indifferent, and 19\% more than indicator plants across all organs (soil affinity $p=0.05$; Table 2 ). Ni treatment did not influence $\mathrm{K}$ uptake in any of the soil affinities ( $p>0.05$; Table 2$)$. Among all soil affinities, $\mathrm{K}$ concentrations were highest in leaves, with leaves containing $26 \%$ and $23 \%$ more $\mathrm{K}$ than anthers and pistils, respectively (organ type $p<0.05$; Table 2 ). Hyperaccumulating endemics and indicators concentrated far more $\mathrm{K}$ into their leaves relative to other organs (soil affinity $\times$ organ type $p<0.0001$; Figure 1A). Hyperaccumulating endemics concentrated more K into anthers than non-hyperaccumulating endemics, but not more than indifferent or indicator species (Figure 1A).

\subsubsection{Phosphorus}

There were no major effects of soil affinity or Ni treatment on $\mathrm{P}$ uptake $(p>0.05$; Table 2). In contrast to trends seen for $\mathrm{K}$, anthers and pistils had $8 \%$ and $6 \%$ more $\mathrm{P}$, respectively, compared to leaves, across all plant affinities (organ type $p<0.0001$; Table 2). Furthermore, there was a significant interaction between soil affinity and organ type; hyperaccumulating endemics took up 50\% more P into their leaves relative to indifferent plants $(p=0.05)$, but only $9 \%$ and $15 \%(p>0.05)$ more than leaves of non-hyperaccumulating endemics and indicators, respectively (Table 2; Figure 1C).

\subsubsection{Calcium}

There were no major effects of soil affinity or Ni treatment on Ca uptake $(p>0.05$; Table 2). Among all soil affinities, Ca concentrations were highest in leaves, with leaves containing $65 \%$ and $71 \%$ more $\mathrm{Ca}$ than anthers and pistils, respectively (tissue type $p<0.0001$; Table 2). While there was a significant affinity $\times$ organ type interaction $(p<0.0001$; Figure 1B), this result was driven by the magnitude of differences across organ types within affinities, rather than by differences across affinities by organ type. Specifically, while Ca concentrations generally followed the same pattern across organ types for all affinities (leaves $>$ anthers > pistils), differences between anthers and pistils were only significant for non-hyperaccumulating endemic and hyperaccumulating endemic species (both $p<0.01$ ). 


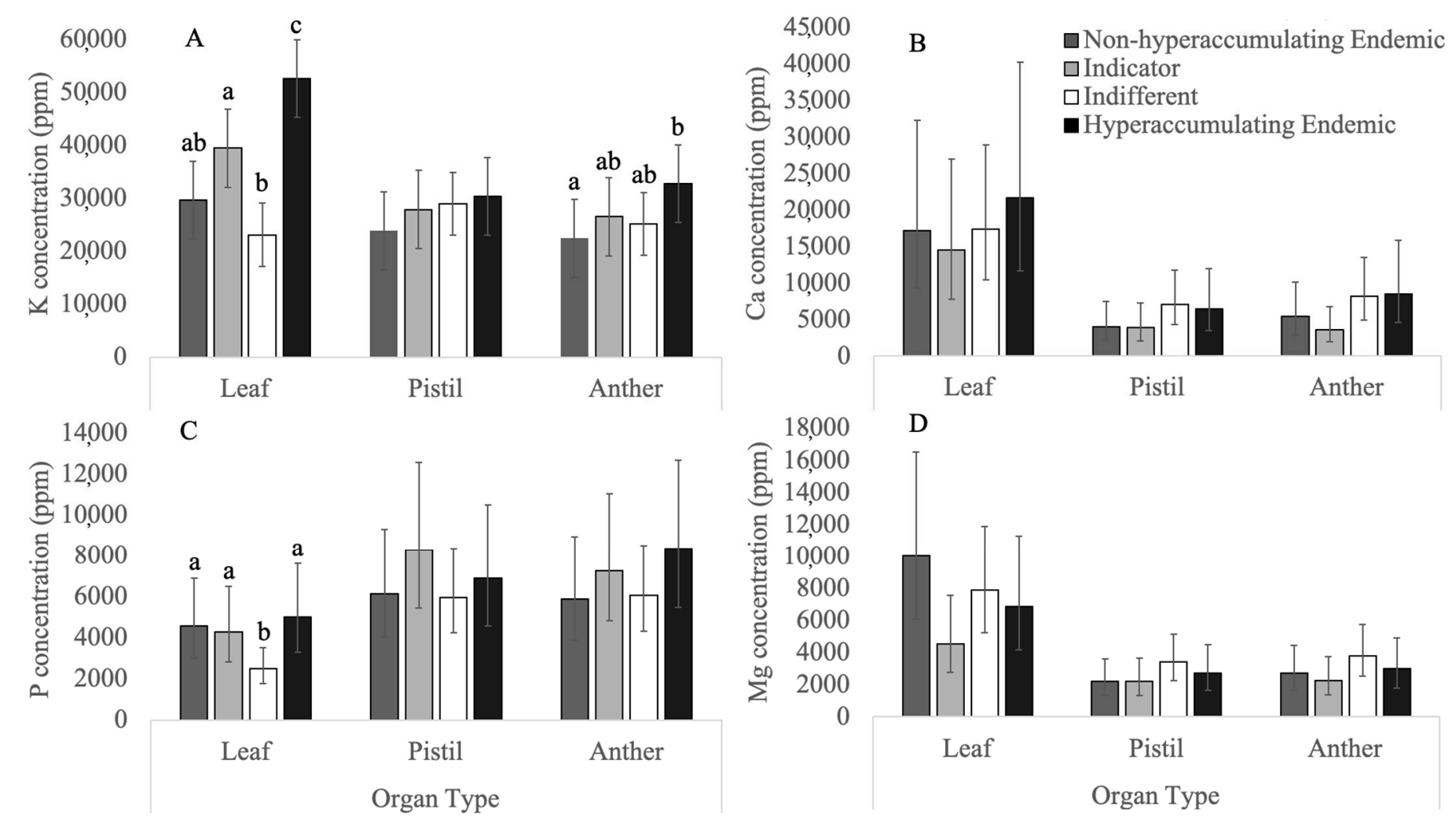

Figure 1. Macronutrient concentrations (back-transformed lsmeans and 95\% confidence intervals) in non-hyperaccumulating endemic, indicator, indifferent, and hyperaccumulating endemic plants, separated by organ type (leaves, pistils, and anthers). Panels (A-D) show K, Ca, P, and Mg concentrations, respectively. Lowercase letters indicate significant pairwise comparisons within organ types $(p<0.05)$.

\subsubsection{Magnesium}

Similar to $\mathrm{Ca}$, there were no major effects of soil affinity or $\mathrm{Ni}$ treatment on $\mathrm{Mg}$ uptake $(p>0.05$; Table 2). Among all soil affinities, $\mathrm{Mg}$ concentrations were highest in leaves, with leaves containing $59 \%$ and $63 \%$ more $\mathrm{Mg}$ than anthers and pistils, respectively (organ type $p<0.0001$; Table 2). While there was a significant affinity $\times$ organ type interaction $(p<0.0001$; Figure 1D), this result was driven by the magnitude of differences across organ types within affinities, rather than by differences across affinities by organ type. Specifically, while $\mathrm{Mg}$ concentrations generally followed the same pattern across organ types for all affinities (leaves $>$ anthers $>$ pistils), differences between anthers and pistils were only significant for non-hyperaccumulating endemic species $(p<0.01)$.

\subsection{Micronutrients}

\subsubsection{Copper}

Soil affinity did not influence $\mathrm{Cu}$ uptake $(p>0.05$; Table 2$)$. Ni treatment inhibited $\mathrm{Cu}$ uptake by $13 \%$ across all soil affinities $(p<0.05$; Table 2$)$. Cu concentrations varied across organ types, and decreased in the following order: anther $>$ pistil $>$ leaf (organ type $p<0.05$ ). Specifically, anthers took up 32\% more Cu relative to pistils and 50\% more $\mathrm{Cu}$ relative to leaves across all soil affinities. However, in contrast to all other affinities, hyperaccumulating endemics showed decreasing $\mathrm{Cu}$ concentrations in the following order: anther $>$ leaf $>$ pistil. Hyperaccumulating endemics tended to accumulate more $\mathrm{Cu}$ into leaves relative to other soil affinities (soil affinity $\times$ organ type $p<0.05$; Figure 2C). This was most significant when comparing hyperaccumulating endemics to indifferent species, where $\mathrm{Cu}$ concentrations were $65 \%$ higher in the leaves of hyperaccumulating endemics $(p \leq 0.05$; Figure 2C). 

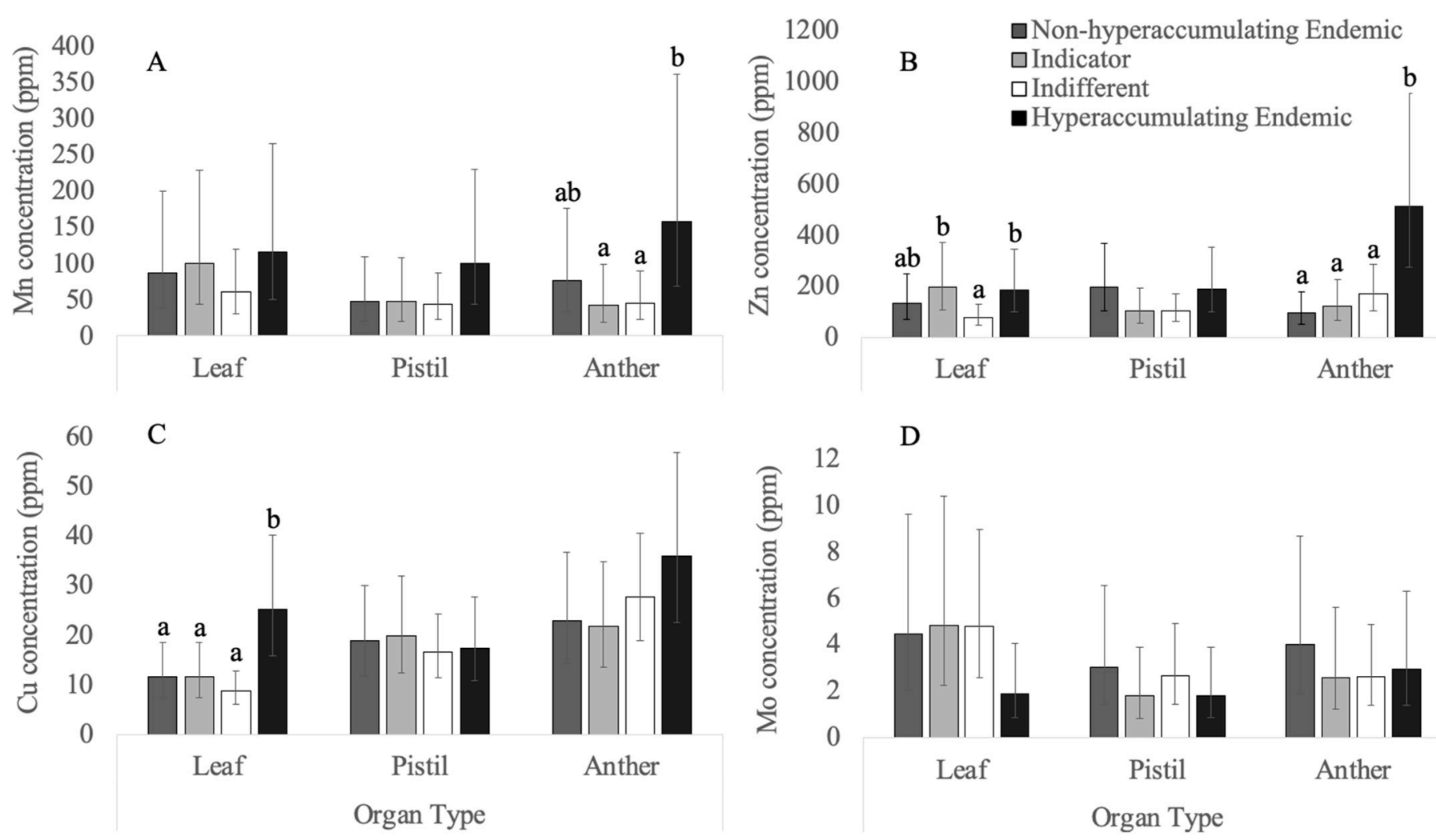

$\mathrm{D}$

Figure 2. Micronutrient concentrations (back-transformed lsmeans and 95\% confidence intervals) in non-hyperaccumulating endemic, indicator, indifferent, and hyperaccumulating endemic plants, separated by organ type (leaves, pistils, and anthers). Panels (A-D) show $\mathrm{Mn}, \mathrm{Zn}, \mathrm{Cu}$, and Mo concentrations, respectively. Lowercase letters indicate significant pairwise comparisons within organ types $(p<0.05)$.

\subsubsection{Manganese}

There were no major effects of soil affinity or Ni treatment on Mn uptake (all $p>0.05$; Table 2). Across all soil affinities, plants accumulated $\mathrm{Mn}$ in the following decreasing order of concentration: leaves $>$ anthers $>$ pistils. Specifically, there was $21 \%$ and $37 \%$ more $\mathrm{Mn}$ in leaves relative to anthers and pistils, respectively (organ type $p>0.05$ ). All nonhyperaccumulators concentrated the most $\mathrm{Mn}$ in their leaves, whereas hyperaccumulating endemics accumulated the greatest concentration of Mn into anthers (soil affinity $\times$ organ type $p<0.001$ Figure 2A).

\subsubsection{Molybdenum}

There were no major effects of soil affinity or Ni treatment on Mo uptake (all $p>0.05$; Table 2). All organ types differed in respect to Mo uptake, with leaves accumulating the highest concentrations, followed by anthers, then pistils (organ type $p<0.05$ ). However, there were significant differences in the allocation patterns across the three above-ground organs between the soil affinities (soil affinity $\times$ organ type $p<0.0001$ ). Hyperaccumulating endemics sequestered the highest concentration of Mo in anthers, which contained $55 \%$ and $58 \%$ more Mo than leaves and pistils, respectively. In contrast, non-hyperaccumulating endemic, indifferent, and indicator species allocated $\sim 50 \%$ more Mo to leaves relative to anthers and pistils (Figure 2D). Furthermore, hyperaccumulating endemics responded differently to $\mathrm{Ni}$ treatment relative to the other soil affinities (soil affinity $\times \mathrm{Ni}$ treatment $p<0.01$; Table 2), where Ni treatment increased overall Mo uptake by $76 \%$. Nickel treatment did not affect Mo uptake in any other soil affinity (all $p>0.05$; Figure 4A). 


\subsubsection{Zinc}

There was no major effect of soil affinity on Zn uptake ( $p>0.05$; Table 2). Nickel treatment significantly reduced $\mathrm{Zn}$ uptake across all soil affinities, as average $\mathrm{Zn}$ concentrations in the $\mathrm{Ni}$ treatment group were reduced by $17 \%$ (Ni treatment $p<0.05$ ). When comparing $\mathrm{Zn}$ uptake across our three organ types, the highest concentration was observed in anthers, with $22 \%$ more than leaves and pistils (organ type $p<0.05$ ). Hyperaccumulating endemics allocated nearly $400 \%$ more $\mathrm{Zn}$ in their anthers relative to all other soil affinities (soil affinity $\times$ organ type $p<0.0001$; Figure 2B).

\subsection{Non-Essential Heavy Metals}

\subsubsection{Chromium}

There were no significant effects of soil affinity or Ni treatment on $\mathrm{Cr}$ uptake $(p>0.05$; Table 2). Across all affinities, $\mathrm{Cr}$ concentrations were highest in anthers, with anthers containing 33\% and 29\% more $\mathrm{Cr}$ than pistils and leaves, respectively (organ type $p<0.001$ ). Hyperaccumulating endemics, on average, accumulated higher concentrations of $\mathrm{Cr}$ into their anthers and leaves, but not pistils, compared to plants of other soil affinities (soil affinity $\times$ organ type $p<0.05$ ). The greatest difference was found when comparing hyperaccumulating endemic and indifferent leaves, where hyperaccumulating endemics had 59\% greater Cr concentrations ( $p<0.01$; Figure 3B).
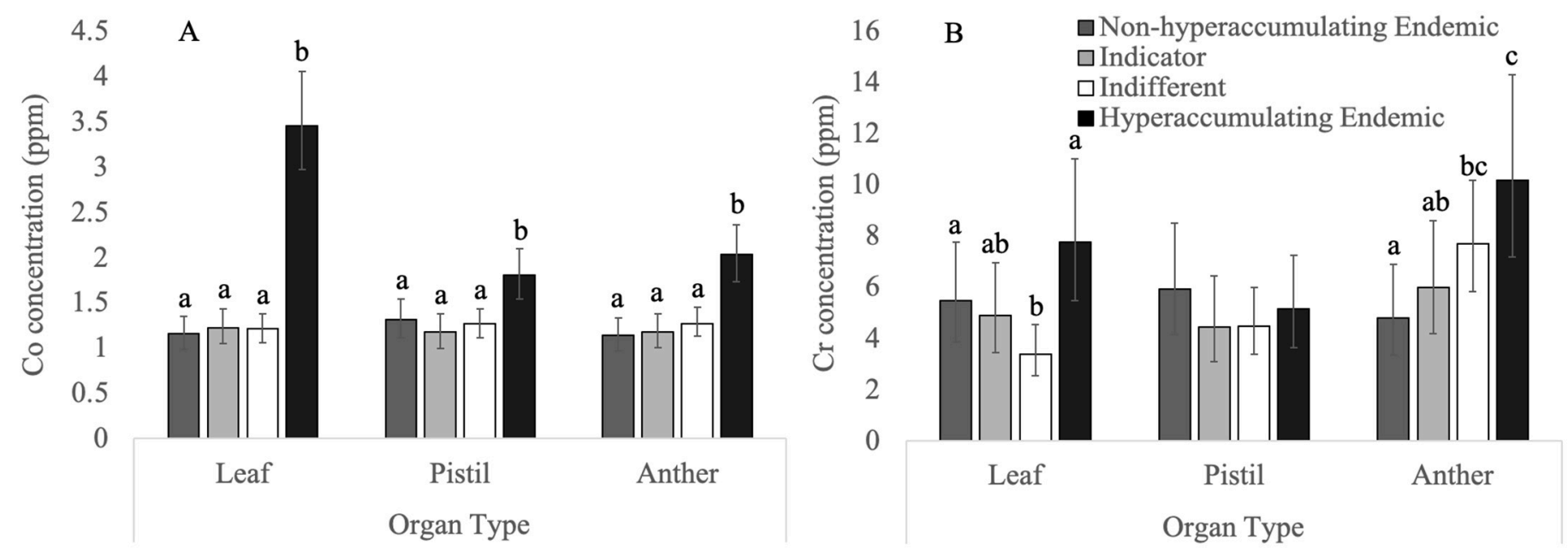

Figure 3. Non-essential heavy metal concentrations (back-transformed lsmeans and 95\% confidence intervals) in nonhyperaccumulating endemic, indicator, indifferent, and hyperaccumulating endemic plants, separated by organ type (leaves, pistils, and anthers). Panels (A,B) show Co and Cr concentrations, respectively. Lowercase letters indicate significant pairwise comparisons within organ types $(p<0.05)$.

\subsubsection{Cobalt}

Soil affinity influenced Co accumulation, as hyperaccumulating endemic plants took up $85 \%$ more Co than non-hyperaccumulating endemic, $81 \%$ more than indifferent, and $86 \%$ more than indicator plants (soil affinity $p<0.001$; Figure $3 \mathrm{~A}$ ). Across the three organ types, leaves showed the highest Co concentrations, with 35\% more than anthers and $34 \%$ more than pistils (organ type $p<0.001$; Figure 3A), but this pattern was largely driven by hyperaccumulating endemic plants, which accumulated much higher Co concentrations into their leaves relative to other soil affinities (soil affinity $\times$ organ type, $p<0.001$ ). The magnitude of difference between organ types of the same soil affinity category were most variable in hyperaccumulating endemics, with $63 \%$ more Co in leaves than in pistils and anthers. In addition, Ni treatment increased Co uptake by $44 \%(p<0.05$; Figure $4 \mathrm{~B})$. This trend depended upon affinity score, where the stimulatory effect of $\mathrm{Ni}$ on Co uptake was 
most exaggerated in the hyperaccumulating endemic category, showing a 195\% increase in

Co uptake, with insignificant effects in all other affinity categories (Figure 4B).

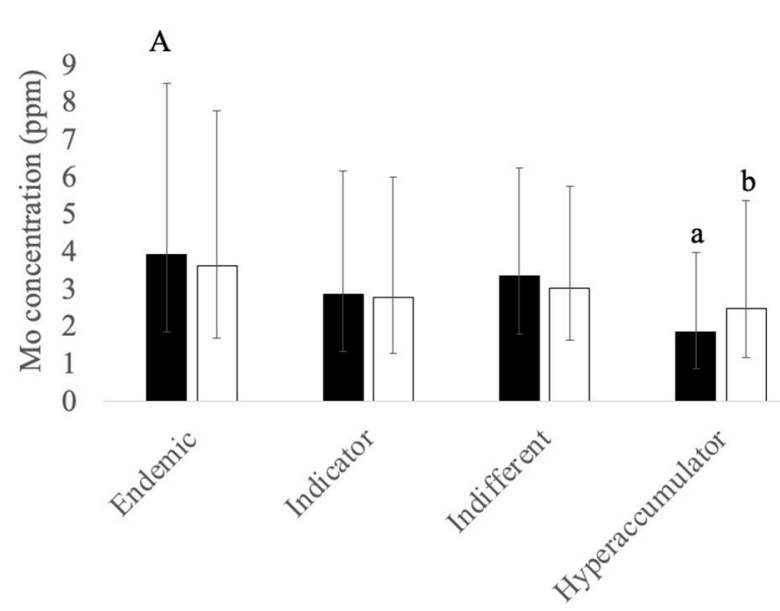

Soil Affinity

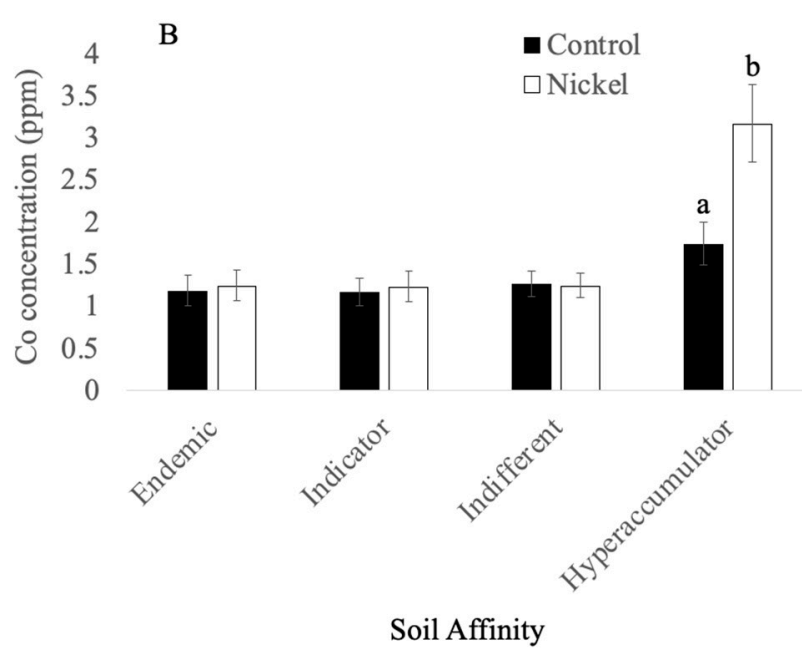

Figure 4. Mo (A) and Co (B) concentrations (back-transformed lsmeans and 95\% confidence intervals) in nonhyperaccumulating endemic, indicator, indifferent, and hyperaccumulating endemic plants, separated by treatment (Ni vs. control). Lowercase letters indicate significant pairwise comparisons within soil affinities $(p<0.05)$.

\section{Discussion}

In accordance with the IUH, in this study the hyperaccumulating endemics often accumulated higher concentrations of nutrients and metals compared to non-hyperaccumulating species, although these differences were often organ-specific. Specifically, while hyperaccumulating endemics accumulated significantly more $\mathrm{K}$ and $\mathrm{Co}$ across all organs, $\mathrm{Cu}$ concentration was higher in leaves only, while Mn and $\mathrm{Zn}$ concentrations were higher in anthers only. Furthermore, hyperaccumulating endemics accumulated significantly more $\mathrm{Co}$ and Mo across all organs when Ni was added to the soil environment. Below, we discuss the significance of these findings as they relate to the serpentine adaptation of hyperaccumulating and non-hyperaccumulating plant species.

We found that hyperaccumulating endemic plants accumulated the highest $\mathrm{K}$ concentrations across all organs relative to other affinity categories (Figure 1A). Increased translocation of $\mathrm{K}$ by plants growing in low-K serpentine environments could be advantageous, as serpentines are characterized as water-deficient soils, and $\mathrm{K}$ has been reported to assist in drought stress and is vital for stomatal regulation [40,41]. Improved tolerance to other environmental stressors, such as excess $\mathrm{Na}$, is also linked with enhanced ability of plants to access $\mathrm{K}$ and other cations in the soil solution [42]. Our data suggest that metal hyperaccumulators may similarly possess the ability to access essential limiting nutrients despite toxic metal cations that are also relatively abundant in the soil solution. Because similar transmembrane carriers are often responsible for transporting metals and essential nutrients [43], metal hyperaccumulation and storage may allow plants to access limiting nutrients by simply upregulating the activity of these carriers in order to overcome uptake competition between cations. In support of this idea, recent studies have found that $\mathrm{Ni}$ hyperaccumulators accumulate high concentrations of $\mathrm{Ca}, \mathrm{K}$, and $\mathrm{P}$ into aboveground tissues, despite the low levels of these elements present in the ultramafic soils in which they grow [20,21]. Furthermore, van der Ent and Mulligan [44] also presented data suggesting that serpentine Ni hyperaccumulators concentrate higher $\mathrm{K}$ concentrations in their tissues compared to non-accumulators, though they did not perform any quantitative comparisons on their data; further studies are needed to determine whether these patterns are widespread in natural populations of hyperaccumulating plants in serpentines and other metal-rich soils. 
Although the only major effect of serpentine affinity on micro- and macronutrient uptake was found for K, we detected several significant interactions between serpentine affinity and organ type for other nutrients. Specifically, we found that $\mathrm{Cu}$ was significantly higher in hyperaccumulating endemic leaves, while $\mathrm{Mn}$ and $\mathrm{Zn}$ were significantly higher in hyperaccumulating endemic anthers. $\mathrm{Cu}$ is essential for plant growth, as it catalyzes redox reactions as a component of metalloproteins responsible for electron transport in chloroplasts and mitochondria [45]. Normal $\mathrm{Cu}$ concentrations in plant tissues range from 5 to $10 \mathrm{ppm}$, while deficiency can occur in leaf concentrations below 2-5 ppm [46,47]. While all affinity categories averaged in normal ranges for leaf $\mathrm{Cu}$ concentration, hyperaccumulating endemic plants contained more than twice the leaf $\mathrm{Cu}$ found in other affinities, suggesting a more effective uptake mechanism for this essential micronutrient. This increased capacity for $\mathrm{Cu}$ uptake into leaves, where it is essential for photosynthesis, may provide a selective advantage for hyperaccumulating plant species in serpentine soils that are often $\mathrm{Cu}$-deficient (but see van der Ent and Reeves [48] for a discussion of $\mathrm{Cu}$ rich ultramafic soils). While hyperaccumulator plants did not significantly differ relative to non-accumulators in terms of overall $\mathrm{Mn}$ or $\mathrm{Zn}$ uptake, hyperaccumulators showed greater uptake into anthers for both elements. Manganese is important for a broad array of metabolic and physiological functions in plants (e.g., photosynthesis, detoxification of reactive oxygen species, enzyme cofactors, etc. [49]), and also appears to be important for pollen viability. Manganese-deficient plants are known to experience delayed anther production, production of smaller anthers, and decreased pollen fertility [50,51]. Furthermore, several nutrients known to occur in relative excess in serpentine soils (e.g., $\mathrm{Fe}, \mathrm{Mg}$, and $\mathrm{Ni}$ ) are known to interfere with Mn uptake [52], thus making efficient and/or enhanced Mn uptake from the soil solution-particularly into anthers-selectively advantageous for serpentineadapted plants. Similarly, $\mathrm{Zn}$ accumulation in anthers by hyperaccumulators was nearly four times greater than that by non-accumulators (Figure 2B). In addition, $\mathrm{Zn}$ is well known to alter pollen quality for plants growing in Zn-deficient soils. For example, Zn deficiency is known to reduce anther size, pollen grain size, pollen viability, and even pollen-pistil interactions [53]. Our data suggest that metal-hyperaccumulating plants acquire higher concentrations of certain important micronutrients than non-hyperaccumulating plants, and specifically into tissues that require them. An important caveat is that we did not measure element concentrations in roots across our study species. While metal hyperaccumulators are defined by metal concentrations in above-ground tissues [7], below-ground accumulation of nutrients clearly has fitness implications, and we suggest that future studies should include both above- and below-ground nutrient profiles of hyperaccumulating and non-accumulating plant species in tests of the IUH.

For the heavy metals studied, we found that hyperaccumulating endemics accumulated significantly more Co across all tissues relative to other affinity categories. In addition, hyperaccumulating endemics generally accumulated more $\mathrm{Cr}$ than other affinity categories overall, though significant differences were only found for leaves (hyperaccumulating endemics had significantly more $\mathrm{Cr}$ than indifferent plants, but not non-hyperaccumulating endemics or indicators) and anthers (hyperaccumulating endemics had significantly more $\mathrm{Cr}$ than non-hyperaccumulating endemic and indicator species, but not indifferent taxa). Both $\mathrm{Co}$ and $\mathrm{Cr}$ are known to be toxic to plants at high concentrations, interfering with photosynthesis in leaves [54] and pollen viability in anthers [55]. The hyperaccumulation of several heavy metals, including $\mathrm{Co}, \mathrm{Cr}$, and $\mathrm{Ni}$, is thought to arise from the upregulation of genes coding for root transporters of other, similar essential ions, such as $\mathrm{Zn}$ [56]. Therefore, heavy metal accumulation and tolerance, in general, would be a necessary consequence of increased nutrient-scavenging efficiency by metal-hyperaccumulating plants. Studies of Ni-hyperaccumulating plants in New Caledonia have also documented elevated levels of heavy metals other than $\mathrm{Ni}$ in hyperaccumulating species relative to non-accumulating species growing in serpentine soils [44]. Furthermore, hyperaccumulator plants were the only plants influenced by our Ni treatment, which stimulated Co and Mo uptake in hyperaccumulating endemics (Figure 4). This is also in accordance with the IUH; in the 
presence of excess metals, such as elevated $\mathrm{Ni}$ in serpentines, access to limiting nutrients becomes even more intense as cations compete with common transport mechanisms for uptake. Selection may therefore favor plants that exhibit increased cation accumulation in response to high metal concentrations in soil.

Our data also suggest that serpentine affinity broadly influences nutrient accumulation in plants, beyond strict comparisons between hyperaccumulating and non-accumulating plant species. For example, hyperaccumulating endemics accumulated significantly higher $\mathrm{P}$ concentrations into their leaves relative to indifferent plants, but not relative to nonhyperaccumulating endemic or indicator species. A similar pattern occurred for K (leaves), Mn (anthers), and Zn (leaves), where indifferent species had among the lowest concentrations of these elements when significant differences were found across affinity types. Other studies have also found differences in element accumulation in endemic vs. nonendemic species in serpentine and other nutrient-limited soils. For example, DeHart et al. [6] and Meindl et al. [34] assessed Ni uptake across plant species with different serpentine soil affinities, and found that endemic plant species accumulated the lowest $\mathrm{Ni}$ concentrations across all tissues relative to non-endemic species when grown in Ni-rich soils. DeHart et al. [6] also found that endemic plants contained higher $\mathrm{Mg}$, $\mathrm{K}$, and $\mathrm{Ca}$ tissue concentrations than non-endemics when grown in serpentine soils. Similarly, Palacio et al. [57] found that gypsum soil endemics displayed enhanced uptake of $\mathrm{P}$ and $\mathrm{N}$ relative to non-endemics when grown in soil with limiting macronutrients and high sulfates. These findings suggest that plants restricted to low-nutrient soils, such as serpentines, possess specific adaptations allowing them to access limiting nutrients (i.e., the specialist model of edaphic endemism [6,57]). In comparison, plants with a lower probability of residing in specific soil environments-e.g., indifferent species-may lack specific physiological adaptations, and instead colonize these soils in order to escape competition in more normal soils, where a tolerance mechanism is seen as a prerequisite (i.e., the refuge model of edaphic endemism [57]). Our findings, taken together with those of Palacio et al. [57] and DeHart et al. [6], show that endemics are capable of restricting the uptake of toxic elements, while simultaneously increasing the acquisition of limiting nutrients like $\mathrm{P}$, relative to non-endemics. In our study, hyperaccumulating endemics accumulated the highest concentrations of $\mathrm{Ni}$ and significantly more $\mathrm{P}$ and $\mathrm{K}$ in their leaves than indifferent plants, but not more than non-hyperaccumulating endemics and indicators, which are both more closely associated to serpentine soils as specialists. Therefore, plants that have close associations with serpentines (i.e., hyperaccumulating endemic, non-hyperaccumulating endemic, and indicator species) appear to have physiological adaptations that allow them to access limiting nutrients better than non-serpentine plants, while simultaneously tolerating elevated soil metal concentrations, either through exclusion or hyperaccumulation. While we did attempt to control for phylogeny by studying species from only one taxonomic family (Brassicaceae), future studies that more narrowly control for phylogeny (e.g., by only utilizing plants from the genus Streptanthus, which contains species from all affinity categories studied in the present paper) would provide further insight into the influence of soil affinity on element accumulation. In addition, not all hyperaccumulating species are endemic to metal-rich substrates $[7,10,13]$; therefore, additional studies that include both endemic and non-endemic hyperaccumulating taxa (and populations from on and off serpentine soils for the non-endemics) would further our understanding of the adaptive significance of metal hyperaccumulation as it relates to the IUH.

Despite low Ca:Mg ratios helping to define serpentine soils, there were no main effects of serpentine affinity on either $\mathrm{Ca}$ or $\mathrm{Mg}$ uptake in our study species. Furthermore, we found no evidence that hyperaccumulating plants differentially accumulated these macronutrients in specific organs (i.e., leaves, anthers, and pistils) compared to other serpentine affinities. One possible explanation for these results is that our experimental soils were not designed to present limited nutrient availability to plant; thus, our ability to detect differences in the uptake of already abundant macronutrients was reduced. Field surveys of hyperaccumulating plants have found that despite relatively low concentrations of soil 
nutrients in serpentine soils, plants growing in these environments have tissue nutrient concentrations within the normal range for terrestrial vascular plants (e.g., S. polygaloides [58]). Notably, Nkrumah et al. [21] found that Ni-hyperaccumulating plants had high Ca:Mg ratios in their above-ground tissues, despite the extremely low $\mathrm{Ca}: \mathrm{Mg}$ ratios that were measured in their native soil. This is important, as the low Ca:Mg ratio in serpentine soils is often cited as the most stressful aspect of plant growth on serpentines, because elevated $\mathrm{Mg}$ makes it difficult for plants to access adequate amounts of Ca [1]. In addition, several studies have found $\mathrm{Ca}$ concentrations to be important for serpentine tolerance in both endemic and hyperaccumulator plant species [59-61]. Therefore, future studies that utilize field-collected serpentine soils or treatment soils that mimic serpentine soil chemistry when comparing nutrient uptake across hyperaccumulating and non-hyperaccumulating plant species would provide additional insight into the inadvertent uptake hypothesis, and are necessary to fully address the adaptive significance of hyperaccumulation in serpentine soils.

Author Contributions: G.A.M. contributed to conceptualization, methodology, data analysis, and writing; M.I.P. contributed to data analysis and writing; D.J.B. contributed to conceptualization, methodology, and writing; M.A.C. contributed to data analysis and writing; T.-L.A. contributed to conceptualization, methodology, resources, supervision, and writing. All authors have read and agreed to the published version of the manuscript.

Funding: This research was funded by a Botany in Action Fellowship from the Phipps Conservatory and Botanical Gardens, an Ivy McManus Diversity Fellowship (University of Pittsburgh), and an Andrew Mellon Predoctoral Fellowship (University of Pittsburgh) to G.A.M., NSF (EAR-IF 0948366) to D.J.B., and NSF (DEB 1020523, 1241006) to T.-L.A.

Institutional Review Board Statement: Not applicable.

Informed Consent Statement: Not applicable.

Data Availability Statement: Data are available from the corresponding author upon request.

Acknowledgments: K. DeHart and C. Murray assisted with plant organ/reward analysis, and E. York and K. Schuller provided greenhouse assistance.

Conflicts of Interest: The authors declare no conflict of interest.

\section{References}

1. Brady, K.U.; Kruckeberg, A.R.; Bradshaw, H.D., Jr. Evolutionary ecology of plant adaptation to serpentine soils. Annu. Rev. Ecol. Evol. Syst. 2005, 36, 243-266. [CrossRef]

2. Harrison, S.; Rajakaruna, N. Serpentine: The Evolution and Ecology of a Model System; University of California Press: Berkeley, CA, USA, 2011; Available online: https:/ / muse.jhu.edu/chapter/954521 (accessed on 1 February 2021).

3. Rajakaruna, N.; Boyd, R. Serpentine Soils. Oxf. Bibliogr. Ecol. 2014. Available online: https://scholarworks.sjsu.edu/biol_pub/53 (accessed on 1 February 2021).

4. Rajakaruna, N.; Boyd, R. Edaphic Factor. Encycl. Ecol. 2008, 46, 1201-1207.

5. Kazakou, E.; Dimitrakopoulos, P.G.; Baker, A.J.M.; Reeves, R.D.; Troumbis, A.Y. Hypotheses, mechanisms and trade-offs of tolerance and adaptation to serpentine soils: From speciesto ecosystemlevel. Biol. Rev. 2008, 83, 495-508. [CrossRef]

6. DeHart, K.S.; Meindl, G.A.; Bain, D.J.; Ashman, T.L. Elemental composition of serpentine plants depends on habitat affinity and organ type. J. Plant Nutr. Soil Sci. 2014, 177, 851-859. [CrossRef]

7. Krämer, U. Metal hyperaccumulation in plants. Annu. Rev. Plant Biol. 2010, 61, 517-534. [CrossRef]

8. Boyd, R.S.; Martens, S.N. Nickel hyperaccumulation by Thlaspi montanum var. montanum (Brassicaceae): A constitutive trait. Am. J. Bot. 1998, 85, 259-265. [CrossRef]

9. Reeves, R.D.; Baker, A.J.M.; Jaffré, T.; Erskine, P.D.; Echevarria, G.; van der Ent, A. A global database for plants that hyperaccumulate metal and metalloid trace elements. New Phytol. 2018, 218, 407-411. [CrossRef] [PubMed]

10. Manara, A.; Fasani, E.; Furini, A.; DalCorso, G. Evolution of the metal hyperaccumulation and hypertolerance traits. Plant Cell Environ. 2020, 43, 2969-2986. [CrossRef] [PubMed]

11. Jhee, E.M.; Boyd, R.S.; Eubanks, M.D. Nickel hyperaccumulation as an elemental defense of Streptanthus polygaloides (Brassicaceae): Influence of herbivore feeding mode. New Phytol. 2005, 168, 331-344. [CrossRef] [PubMed]

12. Vesk, P.A.; Reichman, S.M. Hyperaccumulators and herbivores-A bayesian meta-analysis of feeding choice Trials. J. Chem. Ecol. 2009, 35, 289-296. [CrossRef]

13. Cappa, J.J.; Pilon-Smits, E.A.H. Evolutionary aspects of elemental hyperaccumulation. Planta 2014, 239, 267-275. [CrossRef] 
14. Eskandari, B.S.; Ghaderian, S.M.; Schat, H. The role of nickel (Ni) and drought in serpentine adaptation: Contrasting effects of Ni on osmoprotectants and oxidative stress markers in the serpentine endemic, Cleome heratensis, and the related non-serpentinophyte, Cleome foliolosa. Plant Soil 2017, 417, 183-195. [CrossRef]

15. Boyd, R.S.; Martens, S.N. The raison d'être for metal hyperaccumulation by plants. In The Vegetation of Ultramafic (Serpentine) Soils; Baker, A.J.M., Proctor, J., Reeves, R.D., Eds.; Intercept: Andover, UK, 1992; pp. 279-289.

16. Boyd, R.; Jaffré, T. Elemental concentrations of eleven new caledonian plant species from serpentine soils: Elemental correlations and leaf-age effects. Northeast. Nat. 2009, 16, 93-110. [CrossRef]

17. Liu, X.; Feng, H.; Fu, J.; Chen, Y.; Liu, Y.; Ma, L.Q. Arsenic-induced nutrient uptake in As-hyperaccumulator Pteris vittata and their potential role to enhance plant growth. Chemosphere 2018, 198, 425-431. [CrossRef]

18. Marschner, P. Mineral Nutrition of Higher Plants, 3rd ed.; Academic Press: San Diego, CA, USA, 2012; pp. $171-178$.

19. Rahimi, A. Kupfermangel bei hoheren Pflanzen. Landwirtch. Forssch. Sonderh. 1970, 25, $27-42$.

20. van der Ent, A.; Mak, R.; de Jonge, M.D.; Harris, H.H. Simultaneous hyperaccumulation of nickel and cobalt in the tree Glochidion cf. sericeum (Phyllanthaceae): Elemental distribution and chemical speciation. Sci. Rep. 2018, 8, 9683. [CrossRef] [PubMed]

21. Nkrumah, P.N.; Tisserand, R.; Chaney, R.L.; Baker, A.J.M.; Morel, J.L.; Goudon, R.; Erskine, P.D.; Echevarria, G.; van der Ent, A. The first tropical 'metal farm': Some perspectives from field and pot experiments. J. Geochem. Explor. 2019, 198, 114-122. [CrossRef]

22. Taylor, S.I.; Macnair, M.R. Within and between population variation for zinc and nickel accumulation in two species of Thlaspi (Brassicaceae). New Phytol. 2006, 169, 505-514. [CrossRef]

23. Deng, T.H.B.; Tang, Y.T.; Sterckeman, T.; Echevarria, G.; Morel, J.L.; Qiu, R.L. Effects of the interactions between nickel and other trace metals on their accumulation in the hyperaccumulator Noccaea caerulescens. Environ. Exp. Bot. 2019, 158, 73-79. [CrossRef]

24. Assunção, A.G.L.; Bleeker, P.; Bookum, W.M.T.; Vooijs, R.; Schat, H. Intraspecific variation of metal preference patterns for hyperaccumulation in Thlaspi caerulescens: Evidence from binary metal exposures. Plant Soil 2007, 303, 289-299. [CrossRef]

25. Keeling, S.M.; Stewart, R.B.; Anderson, C.W.N.; Robinson, B. Nickel and Cobalt Phytoextraction by the HyperaccumulatorBerkheya coddii: Implications for Polymetallic Phytomining and Phytoremediation. Int. J. Phytoremediation 2003, 5, 235-244. [CrossRef] [PubMed]

26. Deng, T.-H.-B.; van der Ent, A.; Tang, Y.-T.; Sterckeman, T.; Echevarria, G.; Morel, J.-L.; Qiu, R.-L. Nickel hyperaccumulation mechanisms: A review on the current state of knowledge. Plant Soil 2018, 423, 1-11. [CrossRef]

27. Minnie, M. Phytoextraction of soil cobalt using hyperaccumulator plants. Int. J. Phytoremediation 2001, 2, 319-329.

28. Homer, F.A.; Morrison, R.S.; Brooks, R.R.; Clemens, J.; Reeves, R.D. Comparative studies of nickel, cobalt, and copper uptake by some nickel hyperaccumulators of the genus Alyssum. Plant Soil 1991, 138, 195-205. [CrossRef]

29. Broadhurst, C.L.; Chaney, R.L.; Angle, J.S.; Erbe, E.F.; Maugel, T.K. Nickel localization and response to increasing Ni soil levels in leaves of the Ni hyperaccumulator Alyssum murale. Plant Soil 2004, 265, 225-242. [CrossRef]

30. Safford, H.D.; Viers, J.H.; Harrison, S.P. Serpentine endemism in California flora: A database of serpentine affinity. Madroño 2005, 52, 222-257. [CrossRef]

31. Safford, H.; Miller, J.E.D. An updated database of serpentine endemism in the California flora. Madroño 2020, 67, 85-104. [CrossRef]

32. Gall, J.E.; Rajakaruna, N. The physiology, functional genomics, and applied ecology of heavy metal-tolerant Brassicaceae. In Brassicaceae: Characterization, Functional Genomics and Health Benefits; Lang, M., Ed.; Nova Science Publishers, Inc.: New York, NY, USA, 2013; pp. 121-148.

33. Baldwin, B.G.; Goldman, D.H.; Keil, D.J.; Patterson, R.; Rosatti, T.J.; Wilken, D.H. (Eds.) The Jepson Manual: Vascular Plants of California; University of California Press: Berkeley, CA, USA, 2012.

34. Meindl, G.A.; Bain, D.J.; Ashman, T.-L. Nickel accumulation in leaves, floral organs and rewards varies by serpentine soil affinity. AoB PLANTS 2014, 6, plu036. [CrossRef]

35. L'Huillier, L.L.; Edighoffer, S. Extractability of nickel and its concentration in cultivated plants in Ni rich ultramafic soils of New Caledonia. Plant Soil. 1996, 186, 255-264. [CrossRef]

36. Chardot, V.; Massoura, S.T.; Echevarria, G.; Reeves, R.D.; Morel, J.-L. Phytoextraction potential of the nickel hyperaccumulators leptoplax emarginata and bornmuellera tymphaea. Int. J. Phytoremediation 2005, 7, 323-335. [CrossRef] [PubMed]

37. Echevarria, G.; Massoura, S.T.; Sterckeman, T.; Becquer, T.; Schwartz, C.; Morel, J.L. Assessment and control of the bioavailability of nickel in soils. Environ. Toxicol. Chem. 2006, 25, 643-651. [CrossRef] [PubMed]

38. Littell, R.C.; Stroup, W.W.; Freund, R.J. SAS for Linear Models; SAS Institute: Cary, NC, USA, 2002.

39. Meindl, G.A.; Bain, D.J.; Ashman, T.-L. Variation in nickel accumulation in leaves, reproductive organs and floral rewards in two hyperaccumulating Brassicaceae species. Plant Soil 2014, 383, 349-356. [CrossRef]

40. Hasanuzzaman, M.; Bhuyan, M.H.M.B.; Nahar, K.; Hossain, S.; Al Mahmud, J.; Hossen, S.; Masud, A.A.C.; Moumita, M.; Fujita, M. Potassium: A vital regulator of plant responses and tolerance to abiotic stresses. Agronomy 2018, 8, 31. [CrossRef]

41. White, P.J. Improving potassium acquisition and utilisation by crop plants. J. Plant Nutr. Soil Sci. 2013, 176, 305-316. [CrossRef]

42. Chen, S.; Polle, A. Salinity tolerance of Populus. Plant Biol. 2010, 12, 317-333. [CrossRef]

43. Liu, J.; Li, K.; Xu, J.; Liang, J.; Lu, X.; Yang, J.; Zhu, Q. Interaction of Cd and five mineral nutrients for uptake and accumulation in different rice cultivars and genotypes. Field Crop. Res. 2003, 83, 271-281. [CrossRef]

44. Van Der Ent, A.; Mulligan, D. Multi-element concentrations in plant parts and fluids of malaysian nickel hyperaccumulator plants and some economic and ecological considerations. J. Chem. Ecol. 2015, 41, 396-408. [CrossRef] [PubMed] 
45. Yruela, I. Copper in plants: Acquisition, transport and interactions. Funct. Plant Biol. 2009, 36, 409-430. [CrossRef]

46. Reuther, W. Copper and soil fertility. In Soil, the Yearbook of Agriculture; U.S. Gov. Printing Office: Washington, DC, USA, 1957; pp. $128-135$.

47. Stevenson, F.J. Cycles of Soil-Carbon, Nitrogen, Phosphorus, Sulfur, Micronutrients; Wiley: New York, NY, USA, 1986.

48. Van Der Ent, A.; Reeves, R.D. Foliar metal accumulation in plants from copper-rich ultramafic outcrops: Case studies from Malaysia and Brazil. Plant Soil 2015, 389, 401-418. [CrossRef]

49. Alejandro, S.; Höller, S.; Meier, B.; Peiter, E. Manganese in plants: From acquisition to subcellular allocation. Front. Plant Sci. 2020, 11, 300. [CrossRef] [PubMed]

50. Sharma, C.P.; Sharma, P.N.; Chatterjee, C.; Agarwala, S.C. Manganese deficiency in maize affects pollen viability. Plant Soil 1991, 138, 139-142. [CrossRef]

51. Sharma, P.N. Pollen fertility in manganese deficient wheat. Trop. Agric. 1992, 69, 21-24.

52. Mukhopadhyay, M.J.; Sharma, A. Manganese in cell metabolism of higher plants. Bot. Rev. 1991, 57, 117-149. [CrossRef]

53. Pandey, N.; Pathak, G.C.; Sharma, C.P. Impairment in reproductive development is a major factor limiting yield of black gram under zinc deficiency. Biol. Plant. 2009, 53, 723-727. [CrossRef]

54. Shanker, A.K.; Cervantes, C.; Loza-Tavera, H.; Avudainayagam, S. Chromium toxicity in plants. Environ. Int. 2005, 31, 739-753. [CrossRef]

55. Mittal, N.; Srivastava, A.K. Cadmium- and Chromium-Induced Aberrations in the Reproductive Biology of Hordeum vulgare. Cytologia 2014, 79, 207-214. [CrossRef]

56. Broadley, M.R.; Willey, N.; Wilkins, J.C.; Baker, A.J.M.; Mead, A.; White, P.J. Phylogenetic variation in heavy metal accumulation in angiosperms. New Phytol. 2001, 152, 9-27. [CrossRef]

57. Palacio, S.; Escudero, A.; Montserrat-Martí, G.; Maestro, M.; Milla, R.; Albert, M.J. Plants Living on Gypsum: Beyond the Specialist Model. Ann. Bot. 2007, 99, 333-343. [CrossRef] [PubMed]

58. Sánchez-Mata, D.; De La Fuente, V.; Rufo, L.; Rodríguez, N.; Amils, R. Localization of Nickel in Tissues of Streptanthus polygaloides Gray (Cruciferae) and Endemic Nickel Hyperaccumulators from California. Biol. Trace Element Res. 2013, 157, 75-83. [CrossRef] [PubMed]

59. Sianta, S.A.; Kay, K.M. Adaptation and divergence in edaphic specialists and generalists: Serpentine soil endemics in the California flora occur in barer serpentine habitats with lower soil calcium levels than serpentine tolerators. Am. J. Bot. 2019, 106, 690-703. [CrossRef] [PubMed]

60. Ghasemi, R.; Share, H.; Sharifi, R.; Boyd, R.S.; Rajakaruna, N. Inducing Ni sensitivity in the Ni hyperaccumulator plant Alyssum inflatum Nyárády (Brassicaceae) by transforming with CAX1, a vacuolar membrane calcium transporter. Ecol. Res. 2018, 33, 737-747. [CrossRef]

61. Ghasemi, R.; Chavoshi, Z.Z.; Boyd, R.S.; Rajakaruna, N. Calcium: Magnesium ratio affects environmental stress sensitivity in the serpentine-endemic Alyssum inflatum (Brassicaceae). Aust. J. Bot. 2015, 63, 39-46. [CrossRef] 